\title{
Application of Ganghwa Mugwort in Combination with Ascorbic Acid for the Reduction of Residual Nitrite in Pork Sausage during Refrigerated Storage
}

\author{
Ko-Eun Hwang ${ }^{1}$, Hyun-Wook Kim¹, Dong-Heon Song ${ }^{1}$, Yong-Jae Kim¹, Youn-Kyung Ham ${ }^{1}$, \\ Choong-Hee Lee ${ }^{1}$, Yun-Sang $\mathrm{Choi}^{2}$, and Cheon-Jei Kim ${ }^{1, *}$ \\ ${ }^{1}$ Department of Food Science and Biotechnology of Animal Resources, Konkuk University, Seoul 143-701, Korea \\ ${ }^{2}$ Food and Biological Resources Examination Division, Korean Intellectual Property Office, Daejeon 302-701, Korea
}

\begin{abstract}
The application of ganghwa mugwort (GM), ascorbic acid (AC), and their combinations for reduction of residual nitrite contents was analyzed in pork sausages during storage of $28 \mathrm{~d}$. Six treatments of pork sausages contained the following: Control (no antioxidant added), AC (0.05\% AC), GM 0.1 (0.1\% GM), GM 0.2 (0.2\% GM), AC+GM 0.1 (0.05\% AC + 0.1\% $\mathrm{GM})$ and $\mathrm{AC}+\mathrm{GM} 0.2(0.05 \% \mathrm{AC}+0.2 \% \mathrm{GM})$. Results showed that the mixture of $0.05 \% \mathrm{AC}$ and $0.2 \% \mathrm{GM}$ was most effective for reducing thiobarbituric acid reactive substances (TBARS) and residual nitrite contents than the control and GM added sausages alone $(p<0.05)$. The color values of all treatments were significantly affected by adding GM (either alone or with AC). Additionally, the total color difference $(\Delta E)$ and hue angle $\left(\mathrm{H}^{\circ}\right)$ values of treatments added with GM were higher than those of the control as the amount of GM increased $(p<0.05)$. However, there were no significant differences in the $\mathrm{pH}$ values between the control and all treatments during the storage period $(p>0.05)$. Our results showed possible applications of antioxidant combination, for preventing the lipid oxidation and decreasing the residual nitrite levels of meat products.
\end{abstract}

Key words: antioxidant, mugwort, ascorbic acid, residual nitrite, pork sausage

\section{Introduction}

Sodium nitrite $\left(\mathrm{NaNO}_{2}\right)$ is one of the important ingredients in meat curing process. It has various roles in meat systems such as color development, lipid oxidation, flavor formation and microbiological safety. In addition, the function of nitrite is the production of the attractive pink color of cured meats, a common indicator of the quality of the cooked meat products preferred by the consumer (Zhang et al., 2007).

However, nitrite can cause the formation of carcinogenic $N$-nitrosamines due to its reaction with secondary amines and amino acids in meat proteins. The potential health risks associated with nitrite in meat products calls for attention on decreasing its amounts considerably. Additionally, as consumers are concerned about the possible harmful effects of nitrite and synthetic food additives, the

\footnotetext{
*Corresponding author: Cheon-Jei Kim, Department of Food Science and Biotechnology of Animal Resources, Konkuk University, Seoul 143-701, Korea. Tel: 82-2-450-3684, Fax: 82-2-444-6695, E-mail: kimcj@konkuk.ac.kr
}

meat industry is continually searching for alternative methods to reduce the concentrations of nitrite in their meat products (Vossen et al., 2012; Zhang et al., 2007).

The ascorbic acid works as reducing agent, which increases shelf-life and improves the color of meat and meat products. Also, the combination of ascorbic acid not only acts synergistically with other antioxidants by regenerating and restoring their antioxidant properties but also decreases the residual nitrite in meat products (Djenane et al., 2002; Fiddler et al., 1981).

Ganghwa mugwort (Artemisia princeps Pamp.) is a perennial plant widely distributed in Japan, Korea, China and Europe. In Oriental countries, including Korea, mugwort is widely used as a food or food additive. This plant contains bioactive compounds, such as phenolics, vita$\operatorname{mins} \mathrm{A}, \mathrm{B}_{1}, \mathrm{~B}_{2}$ and $\mathrm{C}$ as well as various minerals (Hwang et al., 2013).

Even though several studies have until now focused on the application of antioxidant combination to inhibit lipid oxidation in various meat products, scientific literature on the residual nitrite contents of sausage added with antioxidant combination is still insufficient. Thus, the objective of 
this study was to investigate the effects of two different antioxidants, a ganghwa mugwort (GM), ascorbic acid (AC) and their combinations in pork sausage as measured by $\mathrm{pH}$, total color difference $(\Delta E)$, hue angle $\left(\mathrm{H}^{\circ}\right)$, thiobarbituric acid reactive substances (TBARS) value, and residual nitrite contents during $28 \mathrm{~d}$ at $4^{\circ} \mathrm{C}$.

\section{Materials and Methods}

\section{Preparation of the ganghwa mugwort (GM)}

Commercial samples of dried ganghwa mugwort were purchased from a local market on Ganghwa Island. After separating the leaves from the dried ganghwa mugwort, they were ground using a blender (KA-2610, Jworld Tech, Korea) for $1 \mathrm{~min}$. Ten $\mathrm{g}$ of ground leaves were extracted with $200 \mathrm{~mL}$ of $50 \%$ ethanol overnight ( $24 \mathrm{~h}$ ) in a shaker at room temperature. The extracts were filtered through filter paper No. 1 (Whatman International, UK) and evaporated with a rotary evaporator (EYELA N-1000, Rikakikai, Japan) at $<50^{\circ} \mathrm{C}$. The products represented the GM.

\section{Preparation of the antioxidant}

The antioxidant of ascorbic aicd (AC: Sewoo Inc, Korea) and ganghwa mugwort extract (GM: $\mathrm{pH}, 6.12 \pm 0.02$; $\mathrm{L}^{*}$ value, $29.21 \pm 0.05$; $\mathrm{a}^{*}$-value, $1.76 \pm 0.33$; $\mathrm{b}^{*}$-value, $-0.77 \pm$ $0.25)$ was prepared according to the formulations: Control (no antioxidant added), AC (0.05\% AC), GM $0.1(0.1 \%$ GM), GM $0.2(0.2 \% \mathrm{GM}), \mathrm{AC}+\mathrm{GM} 0.1(0.05 \% \mathrm{AC}+$ $0.1 \% \mathrm{GM})$ and $\mathrm{AC}+\mathrm{GM} 0.2(0.05 \% \mathrm{AC}+0.2 \% \mathrm{GM})$.

\section{Preparation of pork sausage}

Fresh pork ham and pork back fat were initially ground through an 8-mm plate. Six batches consisted of differing in composition with respect to the addition of antioxidant combination (see above section preparation of the antioxidant). For each batch of emulsion sausage, pork meat $(60 \%)$, pork back fat $(20 \%)$, and ice $(20 \%)$, sodium chloride $(\mathrm{NaCl}, 1.5 \%)$, sodium tripolyphosphate $(0.3 \%)$, and sodium nitrite $\left(\mathrm{NaNO}_{2}, 150 \mathrm{ppm}\right)$, antioxidant (see above section preparation of the antioxidant) were emulsified using silent cutter (Cutter Nr-963009, Hermann Scharfen GmbH \& Co, Germany), and then the each batter was stuffed into collagen casings (\#240, NIPPI Inc., Japan; approximate diameter, $25 \mathrm{~mm}$ ) using stuffer (Stuffer IS-8, Sirman, Italy). The pork sausage was heated at $75 \pm 1^{\circ} \mathrm{C}$ (central temperature) for $30 \mathrm{~min}$ in a smoke chamber. After heated, the cooked pork sausages were packaged refrigerated at $4^{\circ} \mathrm{C}$ and used for further analysis after 0,7 , 14,21 , and $28 \mathrm{~d}$.

\section{pH}

The $\mathrm{pH}$ of $5 \mathrm{~g}$ samples blended with $20 \mathrm{~mL}$ distilled water for $60 \mathrm{~s}$ in a homogenizer (Ultra-Turrax T25, Janke and Kunkel, Germany) was determined with a $\mathrm{pH}$ meter (Model 340, Mettler-Toledo GmbH, Switzerland).

\section{Color}

Color changes in the sausage during storage were monitored with a colorimeter (Chroma meter CR-210, Minolta, Japan) using an 8-mm-diameter measuring area and a 50mm-diameter illumination area. Color was expressed with $L^{*}(100=$ white, $0=$ black), a* (positive $=$ redness, negative $=$ greenness), and $b^{*}$ (positive $=$ yellowness, negative = blueness) values. The colorimetric difference between a sample and a white standard reflectance plate, total color difference $(\Delta E)$, was calculated using the equation: $\Delta E=$ $\left[\left(\mathrm{L}^{*}-\mathrm{L}\right)^{2}+\left(\mathrm{a}^{*}-\mathrm{a}\right)^{2}+\left(\mathrm{b}^{*}-\mathrm{b}\right)^{2}\right]^{1 / 2}\left(\mathrm{~L}^{*}=97.83, \mathrm{a}^{*}=-0.43, \mathrm{~b}^{*}\right.$ $=+1.98)$. Additionally, hue angle $\left(\mathrm{H}^{\circ}\right)$ was calculated with the following formula: $\left(\mathrm{H}^{\circ}\right.$; $\operatorname{Tan}^{-1}\left(\mathrm{~b}^{*} / \mathrm{a}^{*}\right)$. Hue angle was estimated as described by Hunt et al. (1991). Color readings were measured on five randomly chosen spots on the pork sausages and were utilized as an estimate of meat discoloration.

\section{Thiobarbituric acid reactive substances (TBARS) values}

Lipid oxidation was assessed in sample triplicates using the 2-thiobarbituric acid (TBA) method of Tarladgis et al. (1960) with minor modifications and was expressed as miligrams of malondialdehyde (MA) per kilogram of sausage. A $10 \mathrm{~g}$ sample was blended with $50 \mathrm{~mL}$ distilled water for $2 \mathrm{~min}$ and then transferred to a distillation tube. The cup used for blending was washed with an additional $47.5 \mathrm{~mL}$ of distilled water, which was added to the same distillation flask with $2.5 \mathrm{~mL} 4 \mathrm{~N} \mathrm{HCl}$ and a few drops of antifoam agent (KMK-73, Shin-Etsu Silicone Co., Ltd., Korea). The mixture was distilled, and $50 \mathrm{~mL}$ of the distillate was collected. Five $\mathrm{mL}$ of $0.02 \mathrm{M}$ TBA in $90 \%$ acetic acid (TBA reagent) was added to test tubes containing $5 \mathrm{~mL}$ of the distillate and mixed well. The tubes were capped and heated in a boiling water bath for 30 min to develop the chromogen and cooled to room temperature. Absorbance was measured at $538 \mathrm{~nm}$ against a blank prepared with $5 \mathrm{~mL}$ distilled water and $5 \mathrm{~mL}$ TBA reagent using a UV/VIS spectrophotometer (Optizen 2120 UV plus, Mecasys Co. Ltd., Korea).

\section{Residual nitrite contents}

Residual nitrite content was determined according to the 
Diazo coupling method (KFDA, 2013) and is expressed as ppm of sausage. Briefly, a $10 \mathrm{~g}$ of ground sample was placed in a $200 \mathrm{~mL}$ volumetric flask to which approximately $150 \mathrm{~mL}$ of preheated distilled water was added. The solution was combined with $10 \mathrm{~mL} 0.5 \mathrm{~N}$ sodium hydroxide and $10 \mathrm{~mL} 12 \%$ ammonium thiosulfate and then heated in a boiling water bath at $80^{\circ} \mathrm{C}$ for $30 \mathrm{~min}$. After cooling, the solution was added up to $200 \mathrm{~mL}$ by ammonium acetate buffer $20 \mathrm{~mL}$ and distilled water. The sample was incubated for $10 \mathrm{~min}$ at room temperature and filtered through filter paper No. 1 (Whatman International, UK). After filtration, $1.5 \mathrm{~mL}$ sulphanilamide solution and $1.5 \mathrm{~mL} \mathrm{~N}$-(1-naphthyl) ethylenediamine dihydrochloride reagent were added to the tube containing $20 \mathrm{~mL}$ of filtrate and kept at room temperature for $30 \mathrm{~min}$. The absorbance at $538 \mathrm{~nm}$ was read in a UV/VIS spectrophotometer (Optizen 2120 UV plus, Mecasys Co. Ltd., Korea). The residual nitrite content was calculated by a standard curve using nitrite solution.

\section{Statistical analysis}

Statistical analysis and comparisons among means were carried out using the statistical package SPSS 18.0 (SPSS Inc., USA). All data were analysed by ANOVA to test the effects of two fixed factors: storage periods $(0,7,14,21$, and $28 \mathrm{~d}$ ) and sausage type (Control, AC, GM0.1, GM0.2, $\mathrm{AC}+\mathrm{GM} 0.1, \mathrm{AC}+\mathrm{GM} 0.2)$. The Duncan's multiple range was applied for comparisons of means, differences were considered significant at $p<0.05$.

\section{Results and Discussion}

\section{pH}

Addition of ganghwa mugwort and/or ascorbic acid in pork sausage did not significantly affect the $\mathrm{pH}$ values, whereas a significant effect from the storage time was no- ted (Table 1). These results agree with the study of Aksu and Kaya (2005), who obtained similar results when the $\mathrm{pH}$ values are not significantly influenced by antioxidant addition. Mansour and Khalil (2000) showed no difference in $\mathrm{pH}$ between controls and antioxidant-added beef patties during chilled storage. Conversely, other studies have demonstrated that ground beef patties containing $0.1 \%$ ascorbic acid decreased meat $\mathrm{pH}$ by about 0.2 units. Ozer and Sariçoban (2010) indicated that chicken patties treated with ascorbic acid $(300 \mathrm{mg} / \mathrm{kg})$ have a lower $\mathrm{pH}$ value than that of the control sample and those containing BHA and $\alpha$-tocopherol. In our study, the samples containing $0.05 \%$ ascorbic acid had no effects on the $\mathrm{pH}$ values of pork sausage during storage. These results are in accordance with the finding of Li et al. (2013) who showed that the $\mathrm{pH}$ values of dry cured sausage were not significantly affected by adding ascorbic acid $(300 \mathrm{mg} / \mathrm{kg})$ during $28 \mathrm{~d}$. The $\mathrm{pH}$ values of control and all treated samples slightly decreased after storage $14 \mathrm{~d}(p<0.05)$. According to Kim (2011), the $\mathrm{pH}$ values of sausage treated with mugwort extract decrease during storage. A study performed by Fernández-López et al. (2007) proposed that the $\mathrm{pH}$ values can be affected by many factors; however, the production of lactic acid by lactic acid bacterial growth is the major reason responsible for the $\mathrm{pH}$ decrease in packaged meats.

\section{Color}

Food processing industries widely utilize various methods to assess color when determining the commercial acceptability of final products. Changes in the total color difference $(\Delta E)$, and the hue angle $\left(\mathrm{H}^{\circ}: 90^{\circ}=\right.$ yellow, $180^{\circ}$ $=$ green, and $0^{\circ}=$ red) values of pork sausage during storage were showed in Table 2-3, respectively. The $\Delta E$ and $\mathrm{H}^{\circ}$ values of the sausage samples indicated significant differences in relation to the level of GM because the yel-

Table 1. The pH values during storage periods of pork sausage containing ganghwa mugwort (GM) either alone or with ascorbic acid (AC)

\begin{tabular}{ccccccc}
\hline \hline $\begin{array}{c}\text { Storage time } \\
\text { (days) }\end{array}$ & Control $^{1}$ & AC & GM 0.1 & GM 0.2 & AC+GM 0.1 & AC+GM 0.2 \\
\hline 0 & $6.15 \pm 0.08^{\mathrm{b}}$ & $6.15 \pm 0.11^{\mathrm{b}}$ & $6.19 \pm 0.08^{\mathrm{b}}$ & $6.22 \pm 0.04^{\mathrm{b}}$ & $6.21 \pm 0.08^{\mathrm{b}}$ & $6.20 \pm 0.10^{\mathrm{b}}$ \\
7 & $6.14 \pm 0.04^{\mathrm{b}}$ & $6.13 \pm 0.03^{\mathrm{b}}$ & $6.16 \pm 0.05^{\mathrm{b}}$ & $6.17 \pm 0.05^{\mathrm{b}}$ & $6.16 \pm 0.04^{\mathrm{b}}$ & $6.17 \pm 0.04^{\mathrm{b}}$ \\
14 & $6.08 \pm 0.03^{\mathrm{b}}$ & $6.06 \pm 0.02^{\mathrm{b}}$ & $6.09 \pm 0.07^{\mathrm{b}}$ & $6.10 \pm 0.04^{\mathrm{b}}$ & $6.07 \pm 0.10^{\mathrm{b}}$ & $6.09 \pm 0.04^{\mathrm{b}}$ \\
21 & $6.07 \pm 0.05^{\mathrm{a}}$ & $6.03 \pm 0.06^{\mathrm{a}}$ & $6.08 \pm 0.06^{\mathrm{a}}$ & $6.09 \pm 0.08^{\mathrm{a}}$ & $6.07 \pm 0.08^{\mathrm{a}}$ & $6.09 \pm 0.07^{\mathrm{a}}$ \\
28 & $6.03 \pm 0.08^{\mathrm{a}}$ & $6.04 \pm 0.03^{\mathrm{a}}$ & $6.05 \pm 0.04^{\mathrm{a}}$ & $6.06 \pm 0.07^{\mathrm{a}}$ & $6.04 \pm 0.06^{\mathrm{a}}$ & $6.05 \pm 0.07^{\mathrm{a}}$ \\
\hline
\end{tabular}

All values are mean \pm SD of the three replicates.

${ }^{\mathrm{a}-\mathrm{b}}$ Means sharing different letters in the same column are significantly different $(p<0.05)$.

${ }^{1}$ Control, no antioxidant: AC: pork sausage containing AC 0.05\%, GM 0.1: pork sausage containing GM 0.1\%, GM 0.2: pork sausage containing GM $0.2 \%$, AC+GM 0.1: pork sausage containing AC $0.05 \%$ and $\mathrm{GM} 0.1 \%$, AC+GM 0.2: pork sausage containing AC $0.05 \%$ and GM $0.2 \%$. 
Table 2. The $\Delta E$ (total color difference) values during storage periods of pork sausage containing ganghwa mugwort (GM) either alone or with ascorbic acid (AC)

\begin{tabular}{ccccccc}
\hline \hline $\begin{array}{c}\text { Storage time } \\
\text { (days) }\end{array}$ & Control & AC & GM 0.1 & GM 0.2 & AC+GM 0.1 & AC+GM 0.2 \\
\hline 0 & $25.23 \pm 0.55^{\mathrm{Ba}}$ & $24.27 \pm 0.28^{\mathrm{Aa}}$ & $26.47 \pm 0.37^{\mathrm{Ca}}$ & $28.38 \pm 1.14^{\mathrm{Ea}}$ & $26.08 \pm 0.87^{\mathrm{Ca}}$ & $27.36 \pm 0.80^{\mathrm{Da}}$ \\
7 & $25.22 \pm 0.53^{\mathrm{Aa}}$ & $24.58 \pm 0.43^{\mathrm{Aa}}$ & $26.50 \pm 0.75^{\mathrm{Ba}}$ & $28.31 \pm 0.72^{\mathrm{Ca}}$ & $26.89 \pm 0.65^{\mathrm{Bb}}$ & $28.22 \pm 0.73^{\mathrm{Cb}}$ \\
14 & $25.95 \pm 0.64^{\mathrm{Bb}}$ & $25.41 \pm 0.41^{\mathrm{Ab}}$ & $27.26 \pm 0.93^{\mathrm{Cb}}$ & $29.37 \pm 0.89^{\mathrm{Eb}}$ & $26.95 \pm 0.68^{\mathrm{Cb}}$ & $28.66 \pm 0.49^{\mathrm{Db}}$ \\
21 & $26.27 \pm 0.38^{\mathrm{Bb}}$ & $25.56 \pm 0.71^{\mathrm{Ab}}$ & $28.32 \pm 0.95^{\mathrm{Cc}}$ & $29.64 \pm 0.63^{\mathrm{Db}}$ & $27.91 \pm 0.58^{\mathrm{Cc}}$ & $29.52 \pm 0.70^{\mathrm{Dc}}$ \\
28 & $26.85 \pm 0.88^{\mathrm{Bc}}$ & $25.66 \pm 0.79^{\mathrm{Ab}}$ & $28.80 \pm 0.88^{\mathrm{Cc}}$ & $29.95 \pm 0.66^{\mathrm{Db}}$ & $28.23 \pm 0.64^{\mathrm{Cc}}$ & $30.08 \pm 0.87^{\mathrm{Dc}}$ \\
\hline
\end{tabular}

All values are mean \pm SD of the three replicates.

A-E Means sharing different letters in the same row are significantly different $(p<0.05)$.

${ }^{\mathrm{a}-\mathrm{c}}$ Means sharing different letters in the same column are significantly different $(p<0.05)$.

Treatments are the same as in Table 1.

Table 3. The $\mathrm{H}^{\circ}$ (hue angle) values during storage periods of pork sausage containing ganghwa mugwort (GM) either alone or with ascorbic acid (AC)

\begin{tabular}{ccccccc}
\hline \hline $\begin{array}{c}\text { Storage time } \\
\text { (days) }\end{array}$ & Control & AC & GM 0.1 & GM 0.2 & AC+GM 0.1 & AC+GM 0.2 \\
\hline 0 & $45.48 \pm 1.98^{\mathrm{B}}$ & $41.43 \pm 2.00^{\mathrm{A}}$ & $61.83 \pm 1.41^{\mathrm{D}}$ & $70.21 \pm 1.98^{\mathrm{F}}$ & $58.74 \pm 1.27^{\mathrm{C}}$ & $66.83 \pm 0.60^{\mathrm{E}}$ \\
7 & $46.00 \pm 1.78^{\mathrm{B}}$ & $41.64 \pm 1.08^{\mathrm{A}}$ & $60.97 \pm 2.15^{\mathrm{D}}$ & $69.56 \pm 0.82^{\mathrm{F}}$ & $58.47 \pm 0.83^{\mathrm{C}}$ & $66.98 \pm 0.71^{\mathrm{E}}$ \\
14 & $45.81 \pm 1.62^{\mathrm{B}}$ & $40.96 \pm 1.50^{\mathrm{A}}$ & $62.03 \pm 1.98^{\mathrm{D}}$ & $69.53 \pm 2.10^{\mathrm{F}}$ & $59.15 \pm 1.41^{\mathrm{C}}$ & $67.37 \pm 0.66^{\mathrm{E}}$ \\
21 & $46.00 \pm 1.09^{\mathrm{B}}$ & $41.86 \pm 0.63^{\mathrm{A}}$ & $62.41 \pm 1.04^{\mathrm{D}}$ & $70.12 \pm 1.08^{\mathrm{F}}$ & $59.06 \pm 1.00^{\mathrm{C}}$ & $67.28 \pm 0.42^{\mathrm{E}}$ \\
28 & $45.17 \pm 1.74^{\mathrm{B}}$ & $40.70 \pm 1.07^{\mathrm{A}}$ & $61.36 \pm 2.17^{\mathrm{D}}$ & $70.87 \pm 0.98^{\mathrm{F}}$ & $59.40 \pm 1.36^{\mathrm{C}}$ & $67.29 \pm 0.86^{\mathrm{E}}$ \\
\hline
\end{tabular}

All values are mean \pm SD of the three replicates.

${ }^{\text {A-F }}$ Means sharing different letters in the same row are significantly different $(p<0.05)$.

Treatments are the same as in Table 1.

lowness values increased with increasing the GM amount, whereas the lightness and redness values decreased with increasing the GM content (lightness, redness and yellowness data not shown). The initial $\Delta E$ values indices of the control and all treated samples ranged from 24.2728.38 with counts slightly increasing from 25.66-30.08 after $28 \mathrm{~d}$ (Table 2). The $\mathrm{H}^{\circ}$ values of all samples ranged from 41.43-70.21 and did not have a significant effect on the storage (Table 3). Among all treatments, the GM 0.2 (either alone or with $\mathrm{AC}$ ) had the greatest effect on the $\Delta E$ and $\mathrm{H}^{\circ}$ values of the sausage samples; this result could be attributed to the brownish color of the GM. These results were similar to those of previous researches which showed that replacing fat by peach dietary fiber in frankfurters increased the $\Delta E$ values (Grigelmo-Miguel et al., 1999). According to Choi et al. (2011), pork batter treated with rice bran fiber showed higher $\mathrm{H}^{\circ}$ values with increasing rice bran fiber concentration than that in the control. Rodríguez-Carpena et al. (2012) reported that higher hue angle values (more green color) were correlated with higher concentrations of chlorophylls and carotenoids, which contribute to the typical green color of the derived products. Mitsumoto et al. (2005) showed that tea catechins were caused discoloration after the addition in chicken patties. Additionally, Karre et al. (2013) rec- ommended that some natural ingredient such as plum products, grape seed extract, pine bark extract, rosemary, and spices all have been shown to affect the color of finished meat products.

\section{TBARS}

Table 4 shows that TBARS was significantly affected $(p<0.05)$ by storage time and the addition of GM (either alone or with $\mathrm{AC}$ ). However, 0,7 , and $14 \mathrm{~d}$ of storage, no remarkable difference was detected between the control and all treatments. TBARS production of samples treated with GM 0.1 was not much different from that of the control. In contrast to the current results, previous researches showed that treatments containing GM $0.05 \%$ and $0.1 \%$ indicate significantly lower TBARS values than the control in chicken samples during storage for $12 \mathrm{~d}$ (Hwang et al., 2013). This trend may be due to the antioxidant activity of nitrite which plays a role in the prevention of lipid oxidation of pork sausage and inhibits oxidative stress. Additionally, Kim (2011) reported that emulsified pork sausage treated with different types of mugwort (powder, juice, and ethanol extract) significantly inhibits lipid oxidation during $28 \mathrm{~d}$ of storage since mugwort contains many ingredients with antioxidant and antimicrobial effects such as polyphenols. 
In our study, the combination of GM and AC was effective in inhibiting lipid oxidation in pork sausage. These results are in agreement with studies by Ismail et al. (2008) who reported that ground beef added mixture of ascorbic acid and $\alpha$-tocopherol prevented lipid oxidation the most, as evidenced by the lowest TBARS values compared to that in the other treatments. A study performed by Nam and Ahn (2003) suggested that the use of ascorbic acid combined with $\alpha$-tocopherol was more beneficial in controlling lipid oxidation than the use of any single antioxidant in ground beef during storage. The synergistic effects of ascorbic acid when used in combination with other antioxidants in meat have been reported by several researchers, who proposed that the synergism might result from the action of mixed free radical scavengers or the combined action of free radical scavengers and metal chelators (Ahn et al., 2004; Calvert and Decker, 1992; Djenane et al., 2002).

\section{Residual nitrite contents}

The initial contents of residual nitrites in control and all treatments ranged from 49.46-57.21 with counts markedly decreasing from 25.93-41.96 ppm after $28 \mathrm{~d}$ (Table 5). These results confirmed the findings of $\mathrm{Li}$ et al. (2013), who reported that residual nitrite contents can be detected approximately $50-70 \%$ of the added nitrite in the meat product immediately after manufacturing process because when nitrite is added in the meat product, it reacts with myoglobin, sulphydryl groups, lipids and proteins. Also, residual nitrite contents declined further during storage due to oxidization to nitric acid $\left(\mathrm{HNO}_{3}\right)$ or transformation to gaseous forms $\left(\mathrm{N}_{2} \mathrm{O}\right.$ and $\left.\mathrm{N}_{2}\right)$. The samples added with antioxidant treatment reduced the residual nitrite contents of pork sausage; in particular, residual nitrite contents were decreased by the combination of GM and $\mathrm{AC}$. These results suggest that GM and $\mathrm{AC}$ in pork sausages have antioxidant properties that decrease residual nitrite. As reported by Li et al. (2013), reductions in residual nitrite contents were probably due to polyphenols and flavonoids, which react with the various bio-compounds present in the plant extract. Kim (2011) also observed in emulsion pork sausage, where mugwort reduced residual nitrite contents during storage periods.

The sausages containing ascorbic acid had lower nitrite contents than those of the control and samples treated with GM alone $(p<0.05)$ at each of the storage periods investigated. These data agree with those of Li et al. (2013), who reported that the presence of ascorbic acid makes nitrite to more quickly reduce nitrite oxide than plant polyphenols. Ahn et al. (2004) reported that ascorbic acid in cured

Table 4. The TBARS values (mg MA/kg) during storage periods of pork sausage containing ganghwa mugwort (GM) either alone or with ascorbic acid $(\mathrm{AC})$

\begin{tabular}{ccccccc}
\hline \hline $\begin{array}{c}\text { Storage time } \\
\text { (days) }\end{array}$ & Control & AC & GM 0.1 & GM 0.2 & AC+GM 0.1 & AC+GM 0.2 \\
\hline 0 & $0.15 \pm 0.02^{\mathrm{a}}$ & $0.15 \pm 0.04^{\mathrm{a}}$ & $0.15 \pm 0.03^{\mathrm{a}}$ & $0.14 \pm 0.02^{\mathrm{a}}$ & $0.14 \pm 0.02^{\mathrm{a}}$ & $0.13 \pm 0.02^{\mathrm{a}}$ \\
7 & $0.19 \pm 0.02^{\mathrm{b}}$ & $0.19 \pm 0.02^{\mathrm{b}}$ & $0.19 \pm 0.03^{\mathrm{b}}$ & $0.19 \pm 0.02^{\mathrm{b}}$ & $0.18 \pm 0.02^{\mathrm{b}}$ & $0.17 \pm 0.02^{\mathrm{b}}$ \\
14 & $0.23 \pm 0.03^{\mathrm{c}}$ & $0.23 \pm 0.02^{\mathrm{c}}$ & $0.22 \pm 0.02^{\mathrm{c}}$ & $0.21 \pm 0.03^{\mathrm{bc}}$ & $0.21 \pm 0.02^{\mathrm{bc}}$ & $0.21 \pm 0.02^{\mathrm{c}}$ \\
21 & $0.23 \pm 0.03^{\mathrm{Bc}}$ & $0.23 \pm 0.04^{\mathrm{Bc}}$ & $0.23 \pm 0.04^{\mathrm{Bc}}$ & $0.22 \pm 0.02^{\mathrm{ABc}}$ & $0.20 \pm 0.02^{\mathrm{Ac}}$ & $0.20 \pm 0.02^{\mathrm{Ac}}$ \\
28 & $0.29 \pm 0.04^{\mathrm{Bd}}$ & $0.28 \pm 0.02^{\mathrm{Bd}}$ & $0.28 \pm 0.02^{\mathrm{Bd}}$ & $0.25 \pm 0.02^{\mathrm{Ad}}$ & $0.24 \pm 0.02^{\mathrm{Ad}}$ & $0.25 \pm 0.02^{\mathrm{Ad}}$ \\
\hline
\end{tabular}

All values are mean \pm SD of the three replicates.

${ }^{A-B}$ Means sharing different letters in the same row are significantly different $(p<0.05)$.

${ }^{\mathrm{a}-\mathrm{d}}$ Means sharing different letters in the same column are significantly different $(p<0.05)$.

Treatments are the same as in Table 1.

Table 5. The residual nitrite contents (ppm) during storage periods of pork sausage containing ganghwa mugwort (GM) either alone or with ascorbic acid (AC)

\begin{tabular}{ccccccc}
\hline \hline $\begin{array}{c}\text { Storage time } \\
\text { (days) }\end{array}$ & Control & AC & GM 0.1 & GM 0.2 & AC+GM 0.1 & AC+GM 0.2 \\
\hline 0 & $57.21 \pm 0.64^{\mathrm{Fe}}$ & $52.44 \pm 0.96^{\mathrm{Ce}}$ & $56.29 \pm 0.61^{\mathrm{Ee}}$ & $55.34 \pm 0.34^{\mathrm{De}}$ & $50.69 \pm 0.49^{\mathrm{Be}}$ & $49.36 \pm 0.42^{\mathrm{Ae}}$ \\
7 & $56.24 \pm 0.64^{\mathrm{Fd}}$ & $51.01 \pm 0.74^{\mathrm{Cd}}$ & $55.26 \pm 0.58^{\mathrm{Ed}}$ & $54.31 \pm 0.49^{\mathrm{Dd}}$ & $49.65 \pm 0.47^{\mathrm{Bd}}$ & $48.33 \pm 0.39^{\mathrm{Ad}}$ \\
14 & $50.28 \pm 0.54^{\mathrm{Fc}}$ & $42.29 \pm 0.70^{\mathrm{Cc}}$ & $49.53 \pm 0.32^{\mathrm{Ec}}$ & $47.11 \pm 0.79^{\mathrm{Dc}}$ & $40.62 \pm 0.54^{\mathrm{Bc}}$ & $37.19 \pm 0.75^{\mathrm{Ac}}$ \\
21 & $46.45 \pm 0.43^{\mathrm{Fb}}$ & $36.54 \pm 0.72^{\mathrm{Cb}}$ & $45.60 \pm 0.74^{\mathrm{Eb}}$ & $42.52 \pm 0.51^{\mathrm{Db}}$ & $34.14 \pm 0.45^{\mathrm{Bb}}$ & $30.02 \pm 0.36^{\mathrm{Ab}}$ \\
28 & $41.96 \pm 0.78^{\mathrm{Fa}}$ & $30.90 \pm 0.78^{\mathrm{Ca}}$ & $41.57 \pm 0.64^{\mathrm{Ea}}$ & $37.19 \pm 0.47^{\mathrm{Da}}$ & $28.06 \pm 0.78^{\mathrm{Ba}}$ & $25.93 \pm 0.18^{\mathrm{Aa}}$ \\
\hline
\end{tabular}

All values are mean \pm SD of the three replicates.

${ }^{\mathrm{A}-\mathrm{F}}$ Means sharing different letters in the same row are significantly different $(p<0.05)$.

${ }^{\mathrm{a}-\mathrm{e}}$ Means sharing different letters in the same column are significantly different $(p<0.05)$.

Treatments are the same as in Table 1. 
meat performs as an effective reducing agent for nitrite scavenger. Our result indicates that the antioxidant combination of GM and AC will be more effective for reducing the residual nitrite level in pork sausage. The nitrite in meat products is a primary problem in formation of carcinogenic volatile $\mathrm{N}$-nitrosamines. In order to reduce the intake of nitrite in meat products, the application of antioxidant combination could be a suitable alternative method to reduce residual nitrite contents in meat products. (Li et al., 2013)

\section{Conclusion}

The present study showed that the antioxidant ganghwa mugwort (GM), ascorbic acid (AC) and their combination did not significantly influence $\mathrm{pH}$, whereas the total color difference $(\Delta E)$ and the hue angle $\left(\mathrm{H}^{\circ}\right)$ values increased significantly with increasing the GM (either alone or with AC) level. Among the all treatments, the mixture of $0.05 \%$ ascorbic acid and $0.2 \%$ ganghwa mugwort was effective in reducing TBARS and residual nitrite contents values compared to control. The antioxidant combination seems to be more attractive since it inhibits lipid oxidation and decreases the residual nitrites level during storage periods. Additional studies on various natural ingredients would be of great interest for studies about meat products due to the potential harmful effects of artificial additives, especially if combined with ganghwa mugwort, which is capable of reducing the residual nitrite contents.

\section{Acknowledgements}

This study was supported (2013-A423-0047) by the Ministry of Education (Republic of Korea). The authors also were partially supported by the Brain Korean 21 Plus (BK 21 Plus) Project form Ministry of Education and Human Resources Development (Republice of Korea).

\section{References}

1. Ahn, H. J., Kim, J. H., Jo C., Lee, J. W., Yook, H. S., Kim, H. Y., and Byun, M. W. (2004) Combined effects of gamma irradiation and a modified atmospheric packaging on the physicochemical characteristics of sausage. Radiat. Res. 71, 51-54.

2. Aksu, M. I. and Kaya, M. (2005) The effect of $\alpha$-tocopherol and butylated hydroxyanisole on the colour properties and lipid oxidation of kavurma a cooked meat product. Meat Sci. 71, 277-283.

3. Calvert, J. T. and Decker, E. A. (1992) Interactions between carnosine and selected antioxidants in ground turkey. J. Food
Qual. 15, 423-433.

4. Choi, Y. S., Choi, J. H., Han, D. J., Kim, H. Y., Lee, M. A., Kim, H. W., Jeong, J. Y., and Kim, C. J. (2011) Effects of rice bran fiber on heat-induced gel prepared with pork salt-soluble meat proteins in model system. Meat Sci. 88, 59-66.

5. Djenane, D., Sánchez-Escalante, A., Beltrán, J. A., and Roncalés, P. (2002) Ability of $\alpha$-tocopherol, taurine and rosemary, in combination with vitamin $\mathrm{C}$, to increase the oxidative stability of beef steaks packaged in modified atmosphere. Food Chem. 76, 407-415.

6. Fernández-López, J., Sayas-Barberá, E., Muñoz, T., Sendra, E., Navarro, C., and Pérez-Alvarez, J. A. (2007) Effect of packaging conditions on shelf-life of ostrich steaks. Meat Sci. 78, 143-152.

7. Fiddler, W., Gates, R. A., Pensabene, J. W., Phillips, J. G., and Wierbicki, E. (1981) Investigations on nitrosamines in irradiationsterilized bacon. J. Agric. Food Chem. 29, 551-554.

8. Grigelmo-Miguel, N., Abadýìas-Serós, M. I., and MartýìnBelloso. O. (1999) Characterisation of low-fat high-dietary fibre frankfurters. Meat Sci. 52, 247-256.

9. Hunt, M. C., Acton, J. C., Benedict, R. C., Calkins, C. R., Cornforth, D. P., Jeremiah, L. E., Olson, D. G., Salm, C. P., Savell, J. W., and Shivas. S. D. (1991) Guidelines for meat color evaluation. In: 44th Annual Reciprocal Meat conference: June 9-12; Manhattan, Kans. Chicago. Ill: Natl. Livestock and Meat Board. pp. 3-17.

10. Hwang, K. E., Choi, Y. S., Choi, S. M., Kim, H. W., Choi, J. H., Lee, M. A., and Kim, C. J. (2013) Antioxidant action of ganghwayakssuk (Artemisia princeps Pamp.) in combination with ascorbic acid to increase the shelf life in raw and deep fried chicken nuggets. Meat Sci. 95, 593-602.

11. Ismail, H. A., Lee, E. J., Ko, K. Y., and Ahn, D. U. (2008) Effects of aging time and natural antioxdants on the color, lipid oxidation and volatiles of irradiated ground beef. Meat Sci. 80, $582-592$.

12. Karre, L., Lopez, K., and Getty, K. J. K. (2013) Natural antioxidants in meat and poultry products. Meat Sci. 94, 220-227.

13. Kim, Y. J. (2011) Effect of the addition method of mugwort on antioxidant effect, total plate counts, and residual nitrite content of emulsified sausages during cold storage. Korean J. Food Sci. An. 31, 122-128.

14. Korea Food and Drug Administration (KFDA). (2013) Korean Food Standards, Analytical methods of residual nitrite in foods, pp. 10.2.25-26.

15. Li, L., Shao, J., Zhu, X., Zhou, G., and Xu, X. (2013) Effect of plant polyphenols and ascorbic acid on lipid oxidation, residual nitrite and $\mathrm{N}$-nitrosamines formation in dry-cured sausage. Int. J. Food Sci. Tech. 48, 1157-1164.

16. Mansour, E. H. and Khalil. A. H. (2000) Evaluation of antioxidant activity of some plant extracts and the application to ground beef patties. Food Chem. 69,135-141.

17. Mitsumoto, M., O'Grady, M. N., Kerry, J. P., and Joe Buckley, D. (2005) Addition of tea catechins and vitamin C on sensory evaluation, colour and lipid stability during chilled storage in cooked or raw beef and chicken patties. Meat Sci. 69, 773-779.

18. Nam, K. C. and Ahn, D. U. (2003) Effects of ascorbic acid and 
antioxidants on the color of irradiated ground beef. J. Food Sci. 68, 1686-1690.

19. Ozer, O. and Sariçoban. C. (2010) The effects of butylated hydroxyanisole, ascorbic acid, and $\alpha$-tocopherol on some quality characteristics of mechanically deboned chicken patty during freeze storage. Czech J. Food Sci. 28,150-160.

20. Rodríguez-Carpena, J. G., Morcuende, D., and Estévez, M. (2012) Avocado, sunflower and olive oils as replacers of pork back-fat in burger patties: effect on lipid composition, oxidative stability and quality traits. Meat Sci. 90, 106-115.

21. Tarladgis. B.G., Watts B. M., Younthan M. T., and Dugan L.
R. (1960) A distillation method for the quantitative determination of malonaldehyde in rancid foods. J. Am. Oil Chemist Soc. 37, 403-406.

22. Vossen E, Doolaege E. H., Moges, H. D., De Meulenaer, B., Szczepaniak, S., Raes, K., and De Smet, S. (2012) Effect of sodium ascorbate dose on the shelf life stability of reduced nitrite liver pâtés. Meat Sci. 91, 29-35.

23. Zhang, X., Kong, B., and Xiong, Y. L. (2007) Production of cured meat color in nitrite-free Harbin red sausage by Lactobacillus fermentum fermentation. Meat Sci. 77, 593-598.

(Received 2014.1.6/Revised 2014.2.24/Accepted 2014.2.28) 